\title{
LITERATURA INDÍGENA BRASILEIRA: ENTRE TRADIÇÃO, CRÍTICA E RESISTÊNCIA
}

\section{BRAZILIAN INDIAN LITERATURE: BETWEEN TRADITION, CRITICISM AND RESISTANCE}

\author{
Leno Francisco DANNER ${ }^{1}$ \\ Julie DORRICO ${ }^{2}$ \\ Fernando DANNER ${ }^{3}$
}

\begin{abstract}
Resumo: Argumentaremos sobre a literatura indígena brasileira produzida a partir da década de 1990 como uma perspectiva estético-política que entrelaça tradição ancestral com e como crítica do presente, resistência cultural e luta política, aliando-se profundamente ao Movimento Indígena brasileiro surgido a partir de fins de 1970 e, em verdade, tornando-se seu instrumento de legitimação normativa. A literatura indígena é posicionamento político e práxis pedagógica dos indígenas por si mesmos e desde si mesmos, direcionados à politização da questão indígena a partir de um profundo diálogo com a sociedade civil acerca de nossa constituição sociocultural e institucional. Assim, propomos como chave de leitura para a literatura indígena sua vinculação ao Movimento Indígena, sua politização radical e sua utilização da tradição como crítica do presente enquanto ferramentas metodológicas para o acesso a ela e, principalmente, para que não se perca de vista seu sentido e sua orientação profundamente políticos e politizantes.
\end{abstract}

Palavras-chave: Literatura Indígena. Tradição. Crítica. Resistência. Desconstrução.

Abstract: This paper explores the Brazilian Indian literature produced since the1990s. This is seen as an aesthetical-political perspective which intertwines ancestral tradition with and as critic of the present, cultural resistance and political struggle, profoundly allying to the Brazilian Indian Movement that appeared in the end of the 1970s, and, actually, becoming its instrument for normative legitimation. Indian literature is understood as political standing and pedagogical praxis of the Indians by and from themselves, directed to the politicization of Indian issues emerging from a profound dialogue with the civil society about our social-cultural and institutional constitution. Therefore, it is argued that the reading key for Indian Literature should be its connection to the Indian Movement, its radical politicization, and its use of tradition as critics of the present as methodological tools for the access to it and mainly not to forget its deep political and politicizing sense and orientation.

Keywords: Indian Literature. Tradition. Criticism. Resistance. Deconstruction.

Para o governo, para todos os governos que se sucederam na história deste país, o problema está resolvido: ignora-se o direito à existência dos índios. A própria imagem que nos é passada na escola conta-nos a seguinte história: "Quando Cabral chegou, o Brasil era habitado por índios". Aí fecha rápido a cortina e pronto: "não há mais índios!”. O Estado prefere continuar ignorando o direito à existência de índios no Brasil, mas eles começam a se fazer representar junto às instituições (KRENAK, 2015, p. 22).

\footnotetext{
1 Doutor em Filosofia (PUCRS). Professor de Filosofia e de Sociologia no Departamento de Filosofia da Fundação Universidade Federal de Rondônia. E-mail: leno_danner@yahoo.com.br.

${ }^{2}$ Doutoranda em Teoria Literária pelo Programa de Pós-Graduação em Letras da Pontifícia Universidade Católica do Rio Grande do Sul (PUCRS). E-mail: juliedorrico@gmail.com.

${ }^{3}$ Doutor em Filosofia (PUCRS). Professor de Filosofia no Departamento de Filosofia da Universidade Federal de Rondônia (UNIR)]. E-mail: fernando.danner@gmail.com.
} 
A literatura passou a ser mais uma das marcas que escrevemos em nossos corpos para contar os saberes que nossa gente detém (MUNDURUKU, 2016, p. 187).

\section{Considerações iniciais}

Neste artigo, queremos desenvolver a conexão apresentada entre o Movimento Indígena brasileiro constituído por lideranças, intelectuais e povos indígenas a partir de fins da década de 1970 e o desenvolvimento da literatura indígena brasileira a partir da década de 1990. Nosso argumento central consiste primeiramente em apontar para um mote similar que demarcou tanto a constituição do Movimento Indígena quanto o desenvolvimento da literatura indígena pelos intelectuais e escritores indígenas: se, no caso da constituição do Movimento Indígena, tratava-se de enfrentar o etnocídio em curso por meio da contraposição à tutela tecnocrática e, assim, com a consolidação dos indígenas como sujeito, condição e causa público-políticas, no caso da constituição da literatura indígena os intelectuais e escritores indígenas deram-se conta de que, para desconstruir as caricaturas, os estereótipos e os folclorismos em torno à figura do índio, era necessário que eles mesmos passassem a produzir e a publicizar as suas obras, apresentando-nos seus valores, sua alteridade, bem como relatando-nos da situação de marginalização, de exclusão e de violência vividas e sofridas pelos povos indígenas no país. Nesse sentido, a literatura indígena assume-se como uma práxis política e politizante, constituída e dinamizada em termos de ativismo, militância e engajamento em torno à condição e à causa indígenas, como reconstrução da compreensão sobre os indígenas, mas agora por eles mesmos e desde si mesmos.

Em segundo lugar, nós procuraremos desenvolver cinco características fundamentais dessa literatura indígena produzida pelos próprios indígenas, quais sejam (a) a correlação profunda entre comunidade-grupo e indivíduo, de modo que o escritor indígena representa, por meio de sua obra, a própria comunidade de que faz parte, utilizando-a como substrato de seu sentido e de sua vinculação público-política, gerando um eu-nós lírico-político que é carnal, vinculado e dependente dessa sua pertença antropológico-comunitária e que a promove estética e politicamente; (b) a utilização do xamanismo como núcleo antropológico, normativo, político e epistemológico tanto para a compreensão do indígena por si mesmo, da contação e da publicização de sua singularidade, quanto em termos de fundamentação de uma perspectiva de crítica social, de resistência cultural e de luta política na sociedade civil de um modo mais geral relativamente à condição indígena; (c) a consequente utilização da tradição ancestral e das experiências de marginalização próprias à colonização com e como crítica do presente; (d) a busca por diálogo intercultural com a sociedade branca, moderna, a partir do 
entendimento de que os indígenas também têm algo a ensinar a esta; e, como síntese de tudo isso, (e) a constituição de uma voz-práxis política e politizante, carnal e vinculada, que se processa, como dissemos acima, em termos de ativismo, de militância e de engajamento do eu-nós lírico-político, recusando a neutralidade, a imparcialidade e a impessoalidade metodológico-axiológicas próprias a posições institucionalistas, cientificistas e tecnicistas e, com isso, colocando a literatura, em sua estrutura anti-sistêmica aberta, inclusiva, participativa e espontânea, como lugar privilegiado para a manifestação das diferenças, das vítimas, como politização direta, abrangente e radical desde os e por parte dos marginalizados.

\section{Do sentido da literatura indígena brasileira como busca por protagonismo político}

A literatura indígena brasileira desenvolve-se, a partir da década de 1990, em consonância profunda com o Movimento Indígena brasileiro surgido em nossa sociedade em fins da década de 1970, assumindo suas intenções, seus princípios e tornando-se, em verdade, sua instância fundamental em termos de legitimação normativa e de fomento público, político e cultural. Para começo de conversa, trata-se de uma literatura efetivamente indígena, isto é, produzida pelos próprios intelectuais e escritores pertencentes às mais diversas etnias nativas. Nesse aspecto, ela se diferencia das e precisa ser particularizada relativamente às literaturas indianista e indigenista: ao passo que a primeira, produto do romantismo moderno transplantado para o Brasil, representava o indígena de modo caricato e extemporâneo, basicamente folclorístico, de modo a produzir uma versão nobre, pura e guerreira dele (própria do pensamento europeu moderno - o indígena como puro e ingênuo porque um ser pré-civilizacional, enquanto infância da humanidade); ao passo que a segunda seria construída por meio das ciências sociais, a partir das observações objetivas, imparciais, impessoais e formais de um analista acadêmico (o indígena como o antípoda da modernidade, mas enquadrado por esta em categorias analíticas, científicas, por esse analista pertencente ao e munido do paradigma normativo da modernidade); a literatura indígena apresenta e publiciza a própria voz-práxis do intelectual, do escritor indígena em sua umbilical ligação e em seu explícito pertencimento ao grupo ou à etnia de que faz parte, à singularidade e à condição indígenas que o definem de modo fundamental - uma literatura autoral, testemunhal, espontânea do indígena por si mesmo, desde si mesmo e sobre si mesmo, em que ele nos conta de si, nos apresenta a sua visão de mundo e, não menos importante, nos relata de modo autobiográfico, mnemônico e testemunhal da situação de marginalização, de exclusão e de 
violência vivida e sofrida ao longo do desenvolvimento de nosso Brasil (THIÉL, 2012, p. 1547; ROMERO, 2010, p. 02; ALMEIDA \& QUEIROZ, 2004, p. 123-139).

É nesse sentido, aliás, que dissemos há pouco que nossa literatura indígena se alinha direta e pungentemente ao Movimento Indígena brasileiro surgido em fins da década de 1970 enquanto organização de povos, lideranças e intelectuais indígenas como forma de constituição do indígena enquanto sujeito, condição e causa públicos, políticos e culturais. No caso do Movimento Indígena brasileiro, o estopim fundamental para essa vinculação pública, política e cultural dos povos, das lideranças e dos intelectuais indígenas foi exatamente a percepção de que a tutela tecnocrática à qual até então estavam submetidos pelo governo federal era, na verdade, um instrumento fundamental não apenas para a descaracterização e para a anulação da cidadania política e do protagonismo sociocultural dos povos indígenas por si mesmos, mas também fator decisivo para a perpetração do etnocídio em curso com os processos institucionais de fomento do desenvolvimento econômico brasileiro de um modo geral e em termos de expansão agrícola, pecuária e exploração mineral nas regiões centrooeste e norte de nosso país em particular. Como nos salienta Ailton Krenak, o fator que permitiu a e que levou à aglutinação desses povos, dessas lideranças e desses intelectuais indígenas enquanto movimento de caráter público, político e cultural foi exatamente a percepção de que os povos indígenas não sobreviveriam ao tipo de projeto de desenvolvimento fomentado por parte dos governos militares, a saber, a expansão agrícola e pecuária e a garimpagem em torno ao centro-oeste e ao norte do Brasil, o que levou à usurpação das terras indígenas e ao consequente etnocídio dali resultante, por meio de matanças, de doenças, de descaracterização cultural etc. (KRENAK, 2017, p. 220; VALENTE, 2017, p. 25-27). Sob os olhos do governo federal, das instituições públicas responsáveis pela questão indígena (como o SPI - Serviço de Proteção aos Índios - e, depois, a FUNAI) e com o próprio consentimento dos militares, os indígenas estariam sendo paulatinamente expulsos de suas terras e mesmo mortos, sem que esses indígenas considerados, na época, como possuindo responsabilidade relativa (enquanto menores, portanto, na atribuição dada a eles pelo governo federal) - tivessem permissão governamental para assumir uma perspectiva de cidadania política que lhes permitisse o protagonismo, o enfrentamento acerca dessa sua situação, um ponto que seria agravado, além disso, pela centralidade de igrejas católicas e evangélicas em assumirem a responsabilidade da gestão e da educação dos povos indígenas, a partir de uma formação calcada basicamente na tradição religiosa eclesiástica e no modelo de costumes propriamente europeu, com a substituição das lideranças, dos valores, dos ritos e das práticas comunais indígenas pelo modelo de 
organização cristã, tendo a Igreja como centro da vida social, cultural, religiosa e política (KRENAK, 2017, p.41-43; TUKANO, 2017, p. 16; KOPENAWA \& ALBERT, 2015, p. 348-349; MUNDURUKU, 2012, p. 23-42).

Portanto, os povos, as lideranças e os intelectuais indígenas compreenderam que somente teriam condições de evitar o etnocídio em curso contra si se assumissem uma perspectiva ativista, militante e engajada em termos públicos, políticos e culturais, como sujeitos, causa e condição públicos, políticos e culturais, rompendo e desconstruindo uma visão muito comum relativamente ao indígena, a saber, de que ele possuiria capacidade relativa e, por conseguinte, não poderia assumir sua cidadania política e posicionar-se em termos de esfera pública, bem como de que seu lugar fundamental seria o canto mais recôndito da mata, junto com os demais animais, mas não na sociedade civil e, nela, sua participação da esfera pública, como sujeito político. Aqui, diante dessa situação, o falar e o agir por si mesmos e desde si mesmos seriam o mote da constituição e da vinculação sociopolítica do Movimento Indígena brasileiro, o que significa que essa perspectiva ativista, militante e engajada passou a ser afirmada como a condição basilar e dinamizadora dos indígenas por si mesmos e desde si mesmos, que minaria os fundamentos da tutela tecnocrática a que estavam submetidos e lhes permitiria essa vinculação pública, política e cultural enquanto sujeitos, condição e causa coletivos, democráticos. Apresentando-se na esfera pública e como sujeito político-cultural, os povos indígenas teriam condições de (a) construírem o seu relato da situação enfrentada por eles, denunciando a violência vivida e sofrida, além de (b) dialogarem com os mais diversos grupos sociais sobre a condição e a causa indígenas - a conquista e a afirmação da cidadania política, nesse sentido, foram vistas pelas lideranças, pelos intelectuais e pelos grupos fundadores do Movimento Indígena brasileiro como a forma por excelência de superação da tutela tecnocrática e, em consequência, como o elemento impulsionador do sujeito, da condição e da causa indígenas como um desafio nacional, como uma das bases a serem assumidas pela nossa democracia então em consolidação. Ressaltamos, novamente, como ponto fundamental para a constituição, a dinamização e a vinculação público-política dos indígenas, em termos de Movimento Indígena, esse objetivo de falar e de agir diretamente, sem mediações institucionalistas, tecnicistas e cientificistas, enquanto marco de uma postura política dos indígenas em nossa sociedade e acerca de sua situação. Esse ponto demarca e direciona a emergência, a vinculação e o ativismo dos povos indígenas, seus intelectuais e suas lideranças, no âmbito sociopolítico democrático que, como dissemos, desconstrói aquela visão dos indígenas como povos basicamente confinados ao mais profundo de nossas matas e 
como incapazes de cidadania política - cidadania política que, em verdade, é para eles a práxis por excelência para a superação de sua situação de marginalização, de exclusão e de violência. Sobre a constituição do Movimento Indígena brasileiro como afirmação da cidadania política e do protagonismo público, político e cultural dos indígenas por si mesmos e desde si mesmos, nos diz Álvaro Tukano:

\begin{abstract}
Para mim, é muito bonito falar para os jovens que dependemos dessa terra, dependemos dos frutos da terra, das águas. Então é por isso que a gente quer a nossa comunicação com os estudantes e universitários. Seja índio ou branco, a gente tem de fazer uma nova sociedade. O Brasil precisa ser dirigido pelos novos, menos contaminados por essa prática de evangelizar e tutelar o índio. Se a tutela fosse uma salvação de fato, eu bateria palmas. Mas ela tem limitado a minha voz, tem atado as minhas mãos e de outros líderes também. Então, o que estou falando é para desatar esse pano que tem vendado as vozes das lideranças, as mãos das lideranças. Acho que o público tem de ouvir diretamente o que os verdadeiros líderes pensam, falam e defendem sobre a questão indígena. É isso que se tem que entender (TUKANO, 2017, p. 26; os destaques são nossos).
\end{abstract}

Falar e agir diretamente, de modo autoral, sem mediações institucionalistas, tecnicistas e cientificistas - esses são, como dissemos, os fundamentos que estiveram na origem do Movimento Indígena brasileiro. Ora, o falar e o agir diretamente implicam exatamente no fato de que a voz-práxis das vítimas possa ser publicizada desde uma perspectiva basicamente autoral, testemunhal, mnemônica e autobiográfica, enquanto relato nu e cru, carnal, vinculado e pungente da condição de exclusão, de marginalização e de violência vividas e sofridas. Esse relato testemunhal, mnemônico e autobiográfico da vítima por si mesma e desde si mesma, que é publicizado e, por isso, politizado pela própria vítima que se assume como sujeito público-político, como condição e causa público-políticas, é dito em primeira pessoa, é uma contação em primeira pessoa tanto de sua singularidade antropológica quanto de sua situação social, política, cultural, institucional e mesmo epistemológica. Note-se, aqui, o ponto de queremos enfatizar: no caso da literatura de minorias de um modo geral e da literatura indígena em particular, esse relato testemunhal, mnemônico e autobiográfico assume um valor central em termos de autoexpressão e, em consequência, de vinculação social, de crítica política. Certamente a literatura de minorias e a literatura indígena possuem multimodalidades literárias diversas, não se restringindo exclusivamente a essa perspectiva autobiográfica, mas é importante, como estamos objetivando nesse texto, perceber nesse relato direto, nessa vozpráxis pungente dita na correlação de narrador e pertença, que confere à literatura de minorias e, nela, à literatura indígena seu sentido profundamente político e politizante, carnal, pungente e vinculado. Trata-se da vítima falando por si mesma e desde si mesma da condição de marginalização, de exclusão e de violência vividas e sofridas, bem como de sua singularidade étnico-antropológica, base - mas também cura - da marginalização. Destituído de mediações 
por parte de instituições, sujeitos, códigos e práticas tecnicistas e cientificistas, ele rompe com a neutralidade, com a imparcialidade, com a impessoalidade e com a formalidade metodológico-axiológicas próprias ao paradigma normativo da modernidade e sua constituição altamente institucionalista, cientificista e tecnicista, tornando-se uma voz-práxis altamente política e politizante, carnal e vinculada da vítima oprimida que percebe na publicização de si, na constituição, na afirmação e no exercício de sua cidadania política o caminho catártico e transformador de sua condição de marginalização, de exclusão e de violência construída política, normativa e historicamente. Esse, conforme pensamos, é o ponto fundamental da cidadania indígena reivindicada e buscada pelo Movimento Indígena brasileiro, a saber, o fato de que esse ativismo, essa militância e esse engajamento na esfera pública e como sujeito político-cultural, essa conquista e essa afirmação da cidadania política possibilitam aos indígenas sua autoafirmação como diferença, como singularidade e, com isso, em consequência, sua postura de crítica social, de resistência cultural e de luta política relativamente à sua condição, uma vez que o etnocídio indígena não é um dado natural, mas exatamente político, normativo, histórico, isto é, construído simbólica e praticamente devendo, por conseguinte, ser enfrentado política e normativamente por meio da práxis. No caso das vítimas, ou mesmo das minorias em geral, a desconstrução de sua situação de marginalização, de exclusão e de violência, situação essa naturalizada e, assim, despolitizada pelos grupos hegemônicos, passa exatamente pela superação da invisibilização, do silenciamento e do privatismo ao qual foram confinadas, o que significa a sua transformação e a sua vinculação como voz-práxis ativista, militante e engajada, constituída e dinamizada em termos de uma cidadania política radical e pungente. Conforme Ailton Krenak, os povos indígenas, enquanto vítimas de nosso processo de modernização conservadora calcada em uma continuidade direta para com nossa sociedade colonial, são memória viva e, por isso, politização direta e pungente de nossa constituição social, cultural, institucional e normativa. Daí porque a afirmação da cidadania política dos indígenas por si mesmos e desde si mesmos, como contraponto à tutela tecnocrática do Estado, à deslegitimação sofrida por nossas elites político-econômicas dirigentes e à descaracterização religioso-cultural levada a efeito por igrejas católicas e evangélicas, represente e leve a uma politização e a uma desnaturalização potentes e abrangentes de nossa história nacional. Sobre o porquê de o governo manter os indígenas em tutela, esta liderança e intelectual indígena nos diz:

Acho que você conhece a história das potências que colonizaram outras regiões do mundo e que tratam os nativos como cidadãos de segunda ou terceira categoria. Se você observar, a Inglaterra e a França mantinham até recentemente colônias na África e na Ásia, onde os nativos tinham o status aproximado da mula ou do cavalo. Aqui, no Brasil, os índios continuam tendo um status parecido com o de animais 
silvestres. Nós somos objetos da atenção do Estado enquanto seres que precisam ser preservados como fauna. Também temos a atenção do Estado como pessoas e indivíduos que precisam ser vigiados para que não entrem num processo de contestação do poder do Estado, de contestação da ordem estabelecida e de questionamento dos crimes que foram praticados contra nosso povo. Nós somos a memória viva e um testemunho sempre muito explícito da história recente da ocupação desta região do mundo. Cada um de nossos meninos sabe como foi que os brancos se tornaram senhores desta terra e quando nós deixamos de ser os donos (KRENAK, 2015, p. 84-86; os destaques são nossos).

Como memória viva e testemunho pungente, como relato nu e cru, autoral, autobiográfico e mnemônico da exclusão, da marginalização e da violência vividas e sofridas, a voz-práxis indígena, uma voz-práxis das vítimas por si mesmas e desde si mesmas, ao assumir-se como cidadania política, como ativismo, militância e engajamento, leva à politização direta e pungente da sociedade brasileira. Nesse sentido, o verdadeiro cerne do Movimento Indígena brasileiro foi exatamente esse, isto é, politizar-se para politizar a sociedade brasileira na qual todos nós, indígenas e não-indígenas, estamos inseridos; politizar a própria causa e condição, publicizando-a, como a condição fundamental para desnaturalizar, historicizar e politizar nossos sujeitos, nossas relações, nossos valores e nossas práticas socialmente hegemônicas; exprimir-se e agir pública, política e culturalmente como fundamento, como mote para a reconstrução de nossa história nacional, como maturação de nossa democracia, como afirmação e valorização das diferenças, mas a partir da voz-práxis dos excluídos, a partir da participação dos marginalizados. Neste aspecto, é importante mencionar-se que o grosso dos intelectuais e dos escritores indígenas brasileiros da atualidade considera o Movimento Indígena brasileiro, sua emergência, sua constituição e sua vinculação públicas, políticas e culturais, como um dos momentos mais fundamentais da história brasileira hodierna, em especial para os povos indígenas que, pela primeira vez em nosso processo de evolução sociopolítico, assumem-se como sujeitos políticos que se enraízam na esfera pública como forma de criticismo, de resistência e de luta - não mais evitando o contato e recolhendo-se ao recôndito de nossas matas, mas exatamente afirmando e retornando à esfera pública democrática, como sujeitos político-culturais que têm algo a dizer sobre a sua situação, que é a condição do próprio Brasil. Por causa desse enraizamento e desse ativismo públicos, políticos e culturais dos povos indígenas por si mesmos e desde si mesmos, Ailton Krenak considera que o Movimento Indígena brasileiro representa, para os povos indígenas em particular, para a sociedade brasileira de um modo mais geral, a segunda descoberta do Brasil. Ele diz:

Eu acho que teve uma descoberta do Brasil pelos brancos em 1500, e depois uma descoberta do Brasil pelos índios nas décadas de 1970 e 1980. A que está valendo é a última. Os índios descobriram que, apesar de eles serem simbolicamente os donos 
do Brasil, eles não têm lugar nenhum para viver nesse país. Terão de fazer esse lugar existir dia a dia. Não é uma conquista pronta e feita. Vão ter de fazer isso dia a dia, e fazer isso expressando sua visão do mundo, sua potência como seres humanos, sua pluralidade, sua vontade de ser e de viver (KRENAK, 2015, p. 248).

Note-se que essa correlação de Movimento Indígena com uma segunda descoberta do Brasil - a mais importante, em verdade, para os povos indígenas - aponta exatamente para o fato de que, conforme Ailton Krenak, os povos indígenas perceberam que precisavam e precisam assumir uma perspectiva crítico-criativa em termos de ativismo, militância e engajamento na esfera público-política, como sujeitos político-culturais que se publicizam, que publicizam a sua condição e a sua causa. O Movimento Indígena brasileiro, por conseguinte, enquanto segunda descoberta do Brasil, consolida uma postura de ativismo, de militância e de engajamento público-políticos dos povos, dos intelectuais e dos escritores indígenas, como contraponto à tutela tecnocrática e em termos de formulação de uma vozpráxis política e politizante, carnal e vinculada dita de modo direto, autoral, autobiográfico, mnemônico e testemunhal acerca de sua condição de marginalização, de exclusão e de violência enquanto um continuum ao longo de nosso processo de constituição como sociedade brasileira. Ora, aqui podemos situar a literatura indígena produzida em consonância com o Movimento Indígena, uma literatura ativista, militante e engajada que busca exatamente a politização da causa indígena e o fomento - a partir daquela voz-práxis autoral acima estabelecida como característica fundamental da expressão do indígena por si mesmo e desde si mesmo - normativo, simbólico e cultural de sua singularidade. Na literatura indígena, desse modo, temos, como seu mote e sua dinâmica centrais, o relato de sua singularidade e a contação de sua condição de marginalização, atribuindo e permitindo ao próprio indígena o direito de dizer publicamente sua situação, sua perspectiva de mundo, suas dores e seus anseios, tudo isso em favor da luta indígena por reconhecimento diante de uma sociedade brasileira que o periferiza, que lhe confere um lugar - institucional, político, cultural, epistêmico, religioso, econômico - bastante periférico e um protagonismo quase nulo.

Como os intelectuais e escritores indígenas começaram a produzir literatura autoral? $\mathrm{O}$ que os levou a isso? Ora, quando nós lemos os testemunhos desses intelectuais e desses escritores indígenas não apenas sobre o Movimento Indígena brasileiro, mas também sobre o desenvolvimento de seu trabalho estético-literário, nós percebemos que, de fato, uma das grandes razões motivadoras (embora não a única, certamente) consiste no incômodo em relação a uma imagem caricata, folclórica e preconceituosa dos e sobre os indígenas, construída de modo extemporâneo e desvinculado da própria alteridade indígena, que lhes 
motiva a desenvolver e a colocar a literatura indígena enquanto o ponto nodal para a autoexpressão e para a autoafirmação indígena e, a partir daqui, para a publicização dessa alteridade indígena. Por outras palavras, um dos motes centrais da produção estético-literária dos e pelos escritores e intelectuais indígenas consiste exatamente na publicização da própria voz dentro de um contexto em que tradicionalmente esses mesmos indígenas teriam sido silenciados, privatizados e relegados às margens de nossa vida social, política, cultural e institucional. Por isso mesmo, o posicionamento político, via voz-práxis estético-literária, torna-se um dos núcleos e um dos objetivos centrais da literatura de autoria indígena, no Brasil hodierno. Como nos contam Daniel Munduruku, Kaká Werá e Ailton Krenak, é essa tentativa de desconstrução dos estereótipos e dos preconceitos relativamente à compreensão pública, política e cultural sobre os indígenas que lhes motiva a assumirem, via voz-práxis estético-literária, uma postura ativista, militante e engajada, que lhes leva a utilizarem a literatura como ferramenta política, como forma de politização, de crítica social e de resistência cultural - inclusive como prática pedagógica para si e para a sociedade em geral, por meio de uma perspectiva ao mesmo tempo catártica, auto-afirmativa e crítico-criativa sobre a situação e a condição dos povos indígenas no país. É nesse sentido, aliás, que Kaká Werá liga de modo umbilical literatura indígena, autoexpressão e autoafirmação com e como crítica social, resistência cultural e ativismo político, uma vez que a literatura indígena, ao conceder a voz, a palavra e a práxis aos indígenas, lhes permite, ao publicizarem-se, desenvolverem sua cidadania política - a literatura, portanto, como levando à consolidação da cidadania indígena, o que aponta para o fato de que o cerne da literatura indígena é, como vimos dizendo, a politização do indígena, de sua condição e de sua causa, ao lhe dar voz e vez, ao lhe permitir acessar a esfera pública como sujeito estético-político.

Para nós, a literatura indígena é uma maneira de usar a arte, a caneta, como uma estratégia de luta política. É uma ferramenta de luta. E por que uma luta política? Porque, à medida que a gente chega na sociedade $\mathrm{e}$ a sociedade nos reconhece como fazedores de cultura, como porta-vozes de saberes ancestrais e intelectuais, ela vai reconhecendo também que existe uma cidadania indígena (WERÁ, 2017, p. 29).

Assim, da conclusão de que, até o início da década de 1990, no caso do Brasil, nós teríamos basicamente literatura indianista e indigenista, isto é, produções estéticas, literárias e acadêmicas produzidas por não-indígenas e, no mais das vezes, constituídas e dinamizadas de modo caricato, extemporâneo e descomprometido relativamente à condição e à causa indígenas - inclusive chegando ao ponto de recolherem dos povos indígenas seus contos, mitos e tradições e publicá-los com autoria do compilador, negando-a aos próprios povos nativos que relataram isso ao estudioso, uma vez que estes mesmos indígenas eram tidos 
apenas como informantes delas (ALMEIDA \& QUEIROZ, 2004, p. 239-245) -, os intelectuais e os escritores indígenas tomam consciência de que precisavam urgentemente produzir e publicizar suas próprias obras, suas próprias visões de mundo, seus próprios relatos acerca de sua situação, sua própria versão da história do Brasil. Como se pode perceber, é a mesma percepção assumida pelo Movimento Indígena brasileiro, de que o protagonismo do próprio indígena, por si mesmo e desde si mesmo, seria, por assim dizer, a tábua de salvação para a anulação, a deslegitimação e o confinamento dos povos indígenas a um lugar totalmente periférico e nulo em relação à vida nacional, à nossa história, à nossa cultura. No caso da constituição, do desenvolvimento e da consolidação pública, política e cultural da literatura indígena, o silenciamento, a invisibilização e o privatismo impostos aos povos indígenas, seus escritores e intelectuais foram combatidos e desconstruídos exatamente com o protagonismo público, político e intelectual deles, com sua visibilização e ativismo na esfera pública por meio da publicação das próprias obras, por meio da politização da própria vozpráxis estético-literária. Mais uma vez, na literatura indígena o ponto focal é exatamente a promoção do Movimento Indígena, de sua luta, por meio de uma literatura militante para a qual a conquista e a universalização da cidadania política aos povos indígenas levaria a uma fala-práxis direta na sociedade civil, como sujeitos público-políticos fundamentais de nosso processo civilizacional e, nele, da questão indígena brasileira. Diz Kaká Werá acerca da emergência e do desenvolvimento da literatura indígena em nosso país, a partir da década de 1990:

\begin{abstract}
Naquela época, em nossos encontros na aldeia Guarani, eu conversava muito com o Daniel Munduruku. Ele já era um educador, formado em filosofia, e dava aula em escola pública. A gente conversava muito sobre como encontrar maneiras de potencializar esse trabalho de difusão. E tanto ele quanto eu gostávamos muito de literatura. Eu já estava ensaiando meus primeiros escritos literários. Então nós sonhamos, naquela época não era ainda criar um movimento de literatura indígena, mas em usar a escrita para falar das nossas culturas. Para falar diretamente. Para se ter uma ideia, até o início dos anos 1990, o que se tem notícia é de que praticamente tudo o que existe de escrito no Brasil sobre o índio, sobre os povos indígenas, sobre as culturas indígenas, não foi escrito por um índio. Foi sempre por um indigenista, por um antropólogo, por um sociólogo, por um estudioso, por um artista, por um poeta, por um escritor. Não que eu ache que isso seja uma coisa errada. Mas eu achava que, na medida em que nós nos tornássemos protagonistas de nossas próprias vozes, isso poderia gerar uma força muito grande, uma estratégia muito potente para se comunicar diretamente com a sociedade. E também para a sociedade ouvir diretamente a voz de um intelectual, de um cidadão, de um pensador, de um curador, de um contador de histórias vindo de um povo indígena (WERÁ, 2017, p. 25-26).
\end{abstract}

O falar e o agir diretamente em termos públicos, políticos e culturais de modo carnal e vinculado, o relatar autobiográfico, mnemônico, testemunhal e autoral da própria singularidade e da própria condição, tudo isso, para esses escritores e para esses intelectuais 
indígenas, seria viabilizado, potencializado pela literatura, uma vez que, por sua estrutura anti-institucionalista, anti-cientificista, não-técnica e anti-sistêmica, ela possuiria um sentido inclusivo e participativo, aberto e espontâneo que não seria permitido e nem viabilizado pelo paradigma normativo da modernidade, em seu sentido institucionalista, cientificista e tecnicista. Na literatura e por meio da voz-práxis estético-literária, as diferenças podem manifestar-se, expressar-se e publicizar-se na sua mais pura espontaneidade (inclusive subvertendo o uso da língua formal!), mas isso simplesmente não seria possível ao paradigma normativo da modernidade, uma vez que este (a) exige a utilização de uma perspectiva metodológico-axiológica imparcial, neutra, impessoal e formal como condição da objetividade; (b) coloca a autorreferencialidade institucional da comunidade de pesquisa e o sujeito epistêmico lógico-técnico como respectivamente a arena-dinâmica e o sujeito fundamentais da construção da objetividade e da validade normativa; e (c) exige institucionalização, isto é, a substituição do sujeito e da ação cotidianos pelo sujeito e pela ação institucionalizados como critério da aplicação das normas e da orientação da evolução social - de modo que o conhecimento e a ação válidos, portanto, apresentam um cunho institucionalista, cientificista e tecnicista, sem politicidade-politização, carnalidade e vinculação (os sujeitos, as práticas e os valores sociais devem sempre ser mediados pela instituição e desde esse prisma basicamente técnico, imparcial, neutro e impessoal). Ora, o falar e o agir diretamente, base, mote e fim da literatura indígena, quer não apenas devolver o protagonismo sobre sua própria condição, sobre sua própria situação aos povos indígenas, mas consolidar exatamente a ideia de que não existe um lugar privilegiado de fala para além da vida cotidiana, para além do ativismo, da militância e do engajamento dos sujeitos sociopolíticos, em particular para as vítimas de nossa modernização conservadora. Em relação a isso, a ideia mais clara consiste em que não se pode substituir, tecnicizar e despolitizar o relato nu e cru das vítimas - estas são insubstituíveis e irrepresentáveis, não podendo ter sua politicidade, sua vinculação e sua carnalidade apagadas, tecnicizadas, como dissemos. Não por acaso, um ponto definidor da escolha pela literatura indígena e de sua orientação em termos de ativismo, militância e engajamento do eu-nós lírico-político está exatamente no incômodo sentido pelos indígenas relativamente às caricaturas, às imagens extemporâneas, abstratas e superficiais feitas sobre eles pelo observador externo. Como diz Ailton Krenak, o motivo central de sua militância em prol da causa indígena e como intelectual e escritor indígena consistiu e consiste em chamar a atenção sempre, permanentemente sobre o fato de que a imagem que temos dos índios é uma construção de fora, do colonizador, reproduzida com mais ou menos intensidade, mas sempre a imagem do colonizador. É contra essa imagem 
que a voz-práxis estético-literária direta, carnal e pungente do próprio indígena por si mesmo e desde si mesmo combate; é contra ela que a literatura indígena encontra seu mote, sua razão de ser, sua destinação:

E o outro desconforto era me identificar como índio, porque índio é um erro de português, plagiando o Oswald, que disse que, quando o português chegou no Brasil, estava uma baita chuva, aí ele vestiu o índio, mas, se estivesse num dia de sol, o índio teria vestido o português, e estaria todo mundo andando pelado por aí. Isso continua valendo até hoje, e eu atualizei dizendo que o índio é um equívoco do português, não um erro, porque o português saiu para ir para a Índia. Mas ele perdeu a pista e veio bater aqui nas terras tropicais de Pindorama, viu os transeuntes da praia e acabou carimbando de índios. Aquele carimbo errado, equívoco, ficou valendo para o resto das nossas relações até hoje, e a resposta para uma pergunta tão direta e simples poderia ser tão direta e simples quanto. Quando foi que eu atinei que tinha que fazer essas coisas que eu ando fazendo nos últimos 50 anos da minha vida, que é quase que repetir o mesmo mantra, dizendo para esse outro: "ô, cara, essa figura que você está vendo no espelho não sou eu não, é você, esse espelhinho que você está me vendendo não sou eu, isso é um equivoco"? E saí do sentimento para a prática na pista dos meus parentes mais velhos do que eu, que estavam sendo despachados da zona rural para as periferias miseráveis do Brasil, o que acontece em qualquer canto, no Norte, no Sul, em qualquer lugar (KRENAK, 2015, p. 239. Cf., ainda: MUNDURUKU, 2016, p. 20-52).

A busca pela desconstrução desse estereótipo produzido e legitimado em termos de colonização, assumido e promovido pela nossa modernização conservadora, por conseguinte, é o que impulsiona o ativismo indígena e, em nosso caso, o desenvolvimento e a constituição da literatura indígena brasileira a partir da década de 1990 - entre outras coisas porque essa compreensão colonial do índio legitima, respalda sua invisibilização, seu silenciamento, seu privatismo, deslegitimando-o e, assim, promovendo diretamente sua descaracterização e o etnocídio dali resultante. No mesmo diapasão, a produção literária sobre os indígenas, mas agora pelos próprios intelectuais e escritores indígenas, situada no horizonte maior do Movimento Indígena brasileiro enquanto práxis pública, política e cultural consolidada, militante e engajada, possibilita a existência de um contradiscurso, leva ao desenvolvimento da contradição em nível social, uma vez que permite a própria autoexpressão e a própria autoafirmação do indígena por si mesmo e desde si mesmo. Essa situação de enfrentamento, de contradição somente pode ser dinamizada no momento em que esse contradiscurso se faz presente socialmente, se vincula no cotidiano da esfera pública, política e cultural. Enquanto existe apenas uma perspectiva epistemológico-política hegemônica, esta se torna totalizante, unidimensional e massificadora, apolítica e despolitizada (principalmente para as diferenças). No caso da literatura indígena, como estamos argumentando, a percepção de que a imagem do índio seria exatamente uma construção calcada em uma perspectiva colonial e eurocêntrica, tanto no âmbito da literatura indianista quanto no que se refere à perspectiva acadêmica eurocêntrica (por ser fundada e dinamizada na perspectiva modernizante das ciências sociais 
europeias), inclusive no que diz respeito ao âmbito sociocultural baseado no modelo antropológico europeu e cristão, leva a essa atitude propositiva de os indígenas criarem e divulgarem publicamente sua própria compreensão sobre si mesmos. Nesse sentido, se as literaturas indianista e indigenista ainda trabalhavam com essa abordagem extemporânea e caricata de um índio mitológico, concebido enquanto figura própria a um passado prémoderno, como puro e simples silvícola anterior à e superado pela civilização, os escritores e intelectuais indígenas, por meio da voz-práxis estético-literária, por meio da literatura indígena, desconstroem essa perspectiva colonial e atualizam a própria imagem, o próprio protagonismo dos povos indígenas. Por outras palavras, a literatura indígena coloca os indígenas como protagonistas do presente, como artífices do presente, e não mais como seres mitológicos e silvícolas de um passado pré-moderno, pré-civilizacional, tornando-os radicalmente políticos e politizantes. Diz Daniel Munduruku sobre isso:

\begin{abstract}
Num dia qualquer, uma menininha quis saber onde ela poderia encontrar as histórias que eu contava para que pudesse ler. Aquela pergunta me pegou de "calças curtas', como se diz. Eu não poderia dizer a ela a bibliografia da USP e nem soube indicar os livros que continham as histórias. Na verdade, fiquei sem resposta. Dias depois, fui a uma grande livraria da cidade e pedi para o vendedor me mostrar onde estavam os livros para crianças que tratavam da temática indígena. Ele me apresentou uma prateleira que trazia uma plaquinha escrita: folclore. Mesmo achando estranha a descrição, fui olhando título a título. Encontrei vários livros abordando o tema, mas nenhum deles escrito por indígenas. Boa parte era mesmo narrativa folclórica dos personagens já conhecidos. Vez ou outra, encontrei alguns títulos que narravam histórias e traziam informações sobre os povos de onde tinham sido extraídas. A maioria, no entanto, repetia a visão estereotipada e excludente, fazendo os leitores acreditar que os povos indígenas eram coisa do passado. Eu tinha que procurar reverter esse quadro. Não era justo que nossos povos figurassem como folclore nas prateleiras, como se fossem personagens de um passado que não existia mais (MUNDURUKU, 2016, p. 172-173. Cf., ainda: JEKUPE, 2009, p. 11-32).
\end{abstract}

Ora, essa ideia de atualizar a imagem do indígena, que implica diretamente em desconstruir-se todo um simbolismo sobre o índio produzido a partir da, por meio da colonização e orientado em termos de uma perspectiva eurocêntrica, cristã e cientificista (lembre-se, nesse último caso, da diferença entre razão e mito, a primeira como elemento propriamente moderno e emancipatório, o segundo como condição fundamental dos povos pré-modernos, que levaria a uma perspectiva dogmática, fundamentalista e irreflexiva). É nesse sentido que a voz-práxis estético-literária indígena assume-se como ativismo, militância e engajamento do eu-nós lírico-político, como autoexpressão e autoafirmação diretas e pungentes na esfera pública e como sujeito político-cultural, uma vez que reconhece que a neutralidade, a imparcialidade e a impessoalidade metodológico-axiológicas, isto é, a mediação e a representação institucionalistas, cientificistas e tecnicistas, despersonalizam, desvinculam e, assim, despolitizam o sujeito epistemológico-político de minorias, retirando 
das vítimas sua centralidade normativa. Em verdade, como nos diz Daniel Munduruku, a neutralidade, a impessoalidade e a imparcialidade metodológico-axiológicas em nada ajudam à causa indígena, ou pouco contribuem para seu fomento, para sua defesa, já que submetem essa voz-práxis direta dos próprios indígenas por si mesmos e desde si mesmo a mediações cientificistas e tecnicistas que colocam a instituição, seus especialistas e sua metodologia lógico-técnica como o lugar, o sujeito, o caminho e o valor por excelência no que se refere à construção da objetividade epistemológico-moral e da validade normativa. Assim, como contraponto tanto às fortes raízes coloniais de nossa sociedade, de sua cultura, de suas instituições e de seus sujeitos sociopolíticos hegemônicos, e também como contraponto a uma perspectiva acadêmica altamente institucionalista, tecnicista e cientificista que coloca a neutralidade, a imparcialidade e a impessoalidade como o núcleo da vinculação na esfera público-política, a literatura indígena enfatiza exatamente o ativismo, a militância e o engajamento do eu-nós lírico-político como seu mote, como seu fim, como sua base, assumindo direta e pungentemente o desvelamento da condição indígena e a promoção da sua causa. Esse duplo contraponto e essa percepção relativamente ao ativismo dos e pelos intelectuais e escritores indígenas, em verdade, é o núcleo da produção literária de Daniel Munduruku, conforme podemos perceber nas suas próprias palavras:

O mestrado, que iniciei em 1992, não consegui concluir. Minhas idas constantes à
aldeia de meus parentes me envolveram mais do que deveriam e as leituras e as
disciplinas foram sendo deixadas para trás. Mais ainda os textos que deveria
escrever para compor a dissertação à qual me propusera.
A teoria não estava me interessando mais que a prática e o comprometimento com
os destinos de meu povo. Preferia ficar lá procurando junto com a comunidade
maneiras de nos livrarmos dos garimpeiros que invadiam nosso território tradicional
atrás de ouro. Faziam isso à revelia da lei nacional que nos protegia. Queriam
arrancar nosso ouro, mas não ligavam se para isso estavam destruindo nosso habitat
natural e ancestral. Não respeitavam a terra ou os rios; nossos territórios ancestrais
(isso tinha aprendido na antropologia); nossos sítios e cemitérios; nossos espaços
sagrados que serviam de referência para a construção de nossa memória ancestral.
Como poderia presenciar isso sem me compadecer? Como poderia ver a violência
acontecendo e tomar o partido da ciência que me dizia que eu deveria ser um
observador imparcial e objetivo? Eu não conseguia. Havia uma dor aguda apertando
meu peito e uma dúvida que me prendia a respiração (MUNDURUKU, 2016,
p. 165-166).

Note-se que a recusa de uma perspectiva teórico-política neutra, imparcial e impessoal tem como foco dois pontos de crítica, de enfrentamento: a construção de uma imagem caricata, folclórica e preconceituosa sobre o índio, feita por sujeitos epistemológico-políticos extemporâneos, herança da colonização, da perspectiva do colonizador; e a ideia da mediação institucionalista, tecnicista e cientificista como condição fundamental e mesmo suficiente para a crítica social, para a transformação política. Para os intelectuais e escritores indígenas, para as minorias de um modo mais geral, a crítica social e a transformação política somente são 
possíveis pela sua politização, isto é, pelo seu aparecimento e pela sua consolidação na esfera público-política, como sujeitos público-políticos. Por isso, conforme nos conta Daniel Munduruku, sua literatura, a literatura indígena é uma literatura militante, uma práxis pedagógica comprometida diretamente com a transformação social, ao dar voz e vez aos indígenas, ao enquadrar e questionar a história oficial de nossa sociedade, ao questionar e enquadrar nosso passado e nosso presente, projetando - agora com a participação das próprias vítimas antes invisibilizadas e silenciadas - o nosso futuro. Enfim, a literatura indígena, enquanto contraponto às literaturas indianista e indigenista, coloca-se como ativismo, militância e engajamento, como crítica social, resistência cultural, luta política e práxis pedagógica, da mesma forma como o Movimento Indígena assume-se como sujeito, condição e causa públicos, políticos e culturais atuais. Sobre essa perspectiva ativista assumida e dinamizada pela literatura indígena, Daniel Munduruku nos diz:

É que para mim a escrita era uma espécie de instrumento pedagógico. Sempre tive no horizonte o objetivo de auxiliar a sociedade brasileira a conhecer, a compreender e a aceitar a diversidade indígena. Era uma questão de honra. Não me via como um escritor, mas como um educador cuja principal tarefa era "jogar piolhos" na cabeça da sociedade e deixar ela se inquietar, pensar, se coçar e refletir sobre sua própria identidade étnica. Até hoje penso assim, mas agora já sei que sou um escritor que faz uma literatura militante, comprometida com a transformação social. [...] passei a aceitar que escrever e ser professor faziam parte do mesmo processo de redescoberta da ancestralidade brasileira (MUNDURUKJU, 2016, p. 177-178).

Na próxima seção, a partir dessa percepção de que a literatura indígena assume uma vinculação e um enraizamento públicos, políticos e culturais em termos de ativismo, de militância e de engajamento, aliando-se diretamente ao Movimento Indígena e buscando uma expressão direta desde a singularidade-alteridade indígena, sem mediações institucionalistas, cientificistas e tecnicistas, como forma de desconstrução dos estereótipos produzidos pela colonização e pela centralidade, nesta, da perspectiva antropológico-cultural eurocêntrica, procuraremos elencar cinco características definidoras da voz-práxis estético-literária indígena, quais sejam: (a) a constituição de um eu-nós lírico-político marcado pela imbricação entre comunidade-grupo e indivíduo, de modo que a escrita leva à afirmação e à promoção da comunidade, sendo, em verdade, uma defesa desta; (b) o xamanismo - e não a racionalização própria à ciência ocidental - enquanto o horizonte, a prática e o princípio definidor da singularidade indígena, a base de sua práxis público-política e de fundação da crítica social, da resistência cultural, da luta política e da perspectiva pedagógica; (c) a literatura indígena fundando-se na tradição ancestral e utilizando-a como crítica do presente; (d) a busca pelo diálogo intercultural com o Ocidente, a tentativa de socializar com este o legado próprio à tradição indígena; e, como síntese de tudo isso, conforme estamos argumentando no texto, 
(e) a constituição de uma voz-práxis política-politizante, carnal e vinculada que se enraíza e se dinamiza na esfera pública sob a forma de ativismo, de militância e de engajamento do sujeito epistemológico-político-estético.

\section{Da literatura indígena como ativismo: entre tradição e crítica do presente}

Como já desenvolvemos na seção anterior, a voz-práxis estético-literária possui uma estrutura anti-sistêmica, anti-institucionalista, não-técnica e anti-cientificista que possibilita a autoexpressão e a autoafirmação a partir da própria singularidade antropológica, respeitando e promovendo a alteridade, em sua publicização e politização, como o sujeito, o lugar, o caminho e o código da crítica. Nesse aspecto, na literatura, a objetividade enquanto neutralidade, imparcialidade e impessoalidade metodológico-axiológicas dá lugar exatamente à voz-práxis em primeira pessoa, autoral, autobiográfica, carnal e vinculada, desde uma perspectiva ativista, militante e engajada. Como vimos acima, é essa a escolha epistemológica, política e estética assumida e utilizada pelos escritores indígenas em termos de construção e de publicização de suas obras, o que significa que sua literatura é uma literatura engajada, militante e ativista em relação à condição e à causa indígenas, aliando-se profundamente ao Movimento Indígena e promovendo-o. E não poderia ser de outro modo, no caso das minorias, no caso das vítimas: seu aparecimento na esfera pública e como sujeitos público-políticos é diretamente politização da sociedade, das instituições, dos sujeitos, das relações, das práticas e dos valores nos quais estão inseridas, uma vez que as minorias, as vítimas são uma construção político-normativa no duplo sentido do termo, isto é, como concepção moralmente negativa, como subhumanidade, como aberração, como inferioridade pura e simples, e como resultado de processos materiais de exclusão, de marginalização e de destruição - a violência material contra as minorias enquanto estando fundada em uma legitimação normativa de caráter negativo acerca delas. Nesse aspecto, o primeiro ponto importante da literatura de minorias, que podemos perceber no caso da literatura indígena, é a profunda ligação entre comunidade-grupo e indivíduo, no sentido de que o escritor de minorias, o escritor indígena constrói sua produção estético-literária tendo por base tanto o arcabouço antropológico-cultural que lhe constitui de modo fundamental (afinal, a minoria, naquele duplo sentido exposto anteriormente, é produzida politicamente por causa de sua alteridade-diferença antropológico-cultural) quanto o relato de sua situação de marginalização, de exclusão e de violência, que se deve exatamente àquela singularidade antropológico-cultural. Se nos lembrarmos novamente da passagem de Ailton Krenak, citada 
acima, de que os povos indígenas são memória viva e testemunho pungente e carnal do processo de constituição e de evolução de nossa sociedade, perceberemos o fato de que as minorias, por meio da reconstrução de sua história e da publicização de sua voz, simplesmente politizam tudo e todos, desconstroem as mistificações culturais e as imagens modelares de nossa sociedade, de nossa cultura, de nossas instituições, de nossos valores e de nossos personagens centrais. As vítimas, por meio do relato de como se tornaram vítimas, não deixam pedra sobre pedra da história oficial e de nossos exemplos políticos modelares.

Portanto, o primeiro aspecto fundamental que gostaríamos de salientar como marca distintiva da literatura de minorias de um modo geral e da literatura indígena em particular é a profunda ligação e dependência entre comunidade-grupo e indivíduo, no sentido de que este constrói e publiciza sua obra-práxis não apenas a partir desse contexto antropológico que lhe constitui (e por causa do qual ele veio a ser escritor de minorias), mas também em nome dessa comunidade ou desse grupo de que ele é parte. Com isso, contra uma perspectiva estético-política desengajada, basicamente individualista, voyeurista, a-histórica e apolítica do indivíduo liberal, o escritor de minorias assume - e nem pode deixar de fazê-lo, posto que sua pertença, sua aparência, sua expressão já lhe colocam diretamente como estigma social, política e normativamente construído - uma postura altamente política e politizante, carnal e vinculada, dando origem a isso que chamamos, nesse artigo, de eu-nós lírico-político, isto é, uma obra-práxis literária que, por carregar o peso da tradição, da história, dos valores e das experiências comunitárias, étnicas, grupais, também é uma obra coletiva, dependente e ligada fundamentalmente à comunidade, por isso mesmo assumindo-se em politização radical e abrangente do grupo e, em consequência, do contexto social, cultural, institucional e epistêmico no qual ele está inserido. No caso da literatura indígena, desse modo, o eu-nós lírico-político, a imbricação entre comunidade-etnia-grupo e escritor individual é sua base epistemológica, política e estética, levando essa mesma obra-práxis a constituir-se, a dinamizar-se e a publicizar-se sob a forma de ativismo, de militância e de engajamento, em defesa do grupo ou da comunidade de que se faz parte, como forma de promoção deste, como desvelamento da situação desse mesmo grupo ou dessa mesma comunidade. Sobre isso, vejamos a seguinte passagem de Eliane Potiguara, em seu livro Metade cara, metade máscara:

Nosso ancestral dizia: Temos vida longa!/Mas caio da vida e da morte/E range o armamento contra nós./Mas enquanto eu tiver o coração aceso/Não morre a indígena em mim/E nem tampouco o compromisso que assumi/Perante os mortos/De caminhar com minha gente passo a passo/E firme em direção ao sol./Sou uma agulha que ferve no meio do palheiro/Carrego o peso da família 
espoliada/Desacreditada, humilhada/Sem forma, sem brilho, sem fama (POTIGUARA, 2004, p. 102-103).

Note-se, nessa passagem, entre outras coisas, (a) a profunda ligação entre a escritora, sua obra e sua pertença étnico-comunitária, pertença étnico-comunitária que é afirmada por ela como o seu núcleo ontogenético e estético-político, (b) a utilização da literatura como denúncia da condição de marginalização, de exclusão e de violência, o que aponta para essa noção de literatura ativista, militante e engajada de que estamos falando enquanto característica fundamental da literatura de minorias e, dentro desta, da literatura indígena, e, finalmente, (c) a perspectiva autobiográfica, mnemônica e testemunhal da própria condição histórica, social, política e existencial do grupo étnico-comunitário (ou em termos de gênero e de sexualidade, quando pensamos em literatura LGBTT e feminista) que rompe com a separação entre ficção e verdade que é pressuposto fundamental da ciência em sua estrutura altamente lógico-técnica, não-estética, o que significa que a literatura de minorias funde esses pólos, colocando a arte, a produção estética a serviço da crítica, da resistência e da luta, ou seja, a serviço da verdade, via publicização da voz, da condição dessas mesmas minorias por si mesmas e desde si mesmas, sem mediações institucionalistas, cientificistas e tecnicistas.

Aqui aparece a segunda característica fundamental e dinamizadora da constituição, do desenvolvimento e da publicização da literatura indígena, a saber, permitimo-nos repetir, o fato de que o eu-nós lírico-político constitui e demarca uma voz-práxis estético-literária carnal, pungente e política-politizante, altamente ativista, militante e engajada. No caso dos escritores indígenas, a autoconsciência acerca dessa condição da literatura indígena é marcante e orienta seja essa correlação de comunidade-grupo e indivíduo-escritor, seja sua perspectiva de crítica social, de resistência cultural e de luta política. Ao possibilitar a autoexpressão e a autoafirmação dos indígenas por si mesmos e desde si mesmos, a partir de sua singularidade antropológica, ela também leva em consequência à contação autoral, em primeira pessoa, de caráter testemunhal da condição de marginalização, de exclusão e de violência vividas e sofridas. Com isso, esse sentido inclusivo, participativo, espontâneo e aberto da literatura de minorias e, nela, da literatura indígena permite que os escritores possam superar a situação de invisibilização, de silenciamento e de privatismo ao qual foram e são submetidos - e isso não apenas por causa do sentido negativo a eles conferido enquanto minorias, mas também pela própria exclusão relativamente às instituições, às técnicas e aos cânones hegemônicos, que legitimam a produção da objetividade epistemológico-política e que legitimam a vinculação dos sujeitos da práxis e a validade de sua voz, mas desde uma perspectiva altamente institucionalista, cientificista e tecnicista. Não por acaso, como fizemos 
ver ao longo da primeira seção desse texto, os escritores indígenas consideram e afirmam a literatura como essa arena, esse instrumento e esse valor fundamentais para sua autoexpressão e, com isso, para sua perspectiva de crítica social, resistência cultural e luta política. E é por isso que podemos ressaltar novamente a similitude e a associação entre Movimento Indígena e literatura produzida pelos escritores indígenas: a vinculação, o ativismo, a militância e o engajamento na esfera pública e como sujeitos político-culturais, via abertura paradigmática propiciada pela voz-práxis estético-literária, via assunção da cidadania política, permite uma postura de desconstrução, de crítica e de politização da condição e da causa indígenas, uma vez que os próprios povos, lideranças e intelectuais indígenas passam a assumir-se como sujeitos crítico-criativos em termos públicos, políticos, culturais e estéticos - doravante, a questão indígena já não pode mais ser trabalhada sem que esses mesmos indígenas tomem parte, inclusive por meio da arte, como sujeitos privilegiados de sua própria situação e de seus próprios anseios:

Antigamente, os brancos falavam de nós à nossa revelia e nossas verdadeiras palavras permaneciam escondidas na floresta. Ninguém além de nós podia escutálas. Então, comecei a viajar para que as pessoas das cidades por sua vez as ouvissem. Onde podia, espalhei-as por suas orelhas, em peles de papel e nas imagens de sua televisão. Elas se propagaram para muito longe de nós e, ainda que acabemos desaparecendo mesmo, continuarão existindo longe da floresta. Ninguém poderá apagá-las. Muitos brancos agora as conhecem. Ao ouvi-las, começaram a pensar: "Foi um filho dos antigos habitantes da floresta que nos falou. Ele viu com seus próprios olhos os seus parentes arderem em febre e seus rios se transformarem em lamaçais! É verdade!".

Nossas palavras para defender a floresta nos foram dadas por Omama. Sua força provém da imagem dos ancestrais do primeiro tempo, de quem somos os fantasmas. Foram eles que nos ensinaram a valentia que me permite falar com firmeza aos grandes homens dos brancos. Por isso, ficam preocupados quando minhas palavras invadem seu pensamento: "Hou! Essa gente da floresta não tem medo! Suas palavras são duras e eles não recuam!". Na primeira vez que me dirigi ao presidente do Brasil (José Sarney), pedi a ele que expulsasse os garimpeiros de nossa floresta. Ele me respondeu, com hesitação: "São numerosos demais! Não tenho nem aviões nem helicópteros suficientes para tanto! Não tenho dinheiro!". Repetiu-me essas mentiras como se eu fosse desprovido de pensamento! Eu trazia em mim a revolta de minha floresta destruída e de meus parentes mortos. Retruquei que com aquelas palavras tortas ele só queria nos enganar e deixar que nossa terra fosse invadida. Depois acrescentei que para falar assim ele devia ser um homem fraco com o espírito cheio de esquecimento, de modo que não podia pretender ser um grande homem de verdade (Kopenawa \& Albert, 2015, p. 389-390; os destaques são nossos).

Importante destacar-se, nessa passagem, a correlação de relato autobiográfico, mnemônico e testemunhal das próprias vítimas acerca de sua condição, a publicização dele e a verdade, o relato em primeira pessoa das vítimas acerca de sua condição como verdade: a experiência vital das minorias como um relato pessoal que expõe de modo nu, cru, carnal e pungente sua situação de marginalização, de exclusão e de violência. Note-se, no mesmo diapasão, que Davi Kopenawa considera exatamente o ativismo, a militância e o engajamento 
na esfera público-política e como sujeito público, político e cultural, em termos de crítica social, resistência cultural e luta política, enquanto o objetivo fundamental de sua produção autoral. Na medida em que se dá a conhecer aos brancos, isto é, na medida em que em que compartilha suas palavras, suas tradições e suas experiências como minoria, Davi Kopenawa crê poder sensibilizar e conscientizar a todos aqueles que o ouvirem sobre sua condição, sobre sua situação, conseguindo, inclusive, apoio democrático com vistas à consecução de suas reivindicações. Note-se, mais uma vez, que a literatura que dali é construída, a literatura que é construída por um escritor de minorias (lembre-se, aliás, que, na passagem anterior, Davi Kopenawa denominou-a de palavras em pele de papel, o que mostra mais uma vez essa compreensão política e essa adaptação cultural da literatura a partir do escritor de minorias) objetiva publicizar a singularidade antropológica e relatar a situação de marginalização, de exclusão e de violência enfrentada pelos povos indígenas no país. Por isso mesmo, a terceira característica fundamental da literatura indígena está exatamente em sua busca pelo diálogo intercultural, pelo diálogo com o branco enquanto o caminho por excelência para a democratização, para a universalização e para a politização da condição e da causa indígenas no país, para sua vinculação como uma questão pública, política e cultural fundamental. No caso de Davi Kopenawa, em verdade, como pudemos ver pela passagem acima, o tornar-se escritor, o colocar suas palavras em peles de papel está diretamente atrelado ao objetivo de publicizar a condição e a causa indígenas à sociedade de um modo geral, buscando um diálogo produtivo com os brancos acerca delas, buscando, em verdade, por meio da própria voz-práxis de um representante dos povos indígenas, falar diretamente com a sociedade brasileira (e mesmo mais além), conscientizando-a acerca da situação dos povos indígenas e, com isso, assumindo protagonismo cidadão em termos políticos, culturais e estéticos. Entregando suas palavras em peles de papel para que as leve aos brancos, Davi Kopenawa diz a Bruce Albert:

Como eu, você ficou mais experiente com a idade. Você desenhou e fixou essas palavras em peles de papel, como pedi. Elas partiram, afastaram-se de mim. Agora desejo que elas se dividam e se espalhem bem longe, para serem realmente ouvidas. Eu lhe ensinei estas coisas para que você as transmita aos seus; aos seus mais anciãos, aos seus pais e sogros, aos seus irmãos e cunhados, às mulheres que você chama de esposas, aos rapazes que irão chamá-lo de sogro. Se lhe perguntarem: "Como você aprendeu estas coisas?", você responderá: "Morei muito tempo nas casas dos Yanomami, comendo sua comida. Foi assim que, aos poucos, sua língua pegou em mim. Então, eles me confiaram suas palavras, porque lhes dói o fato de os brancos serem tão ignorantes a seu respeito". [...]

Gostaria que os brancos parassem de pensar que nossa floresta é morta e que ela foi posta lá à toa. Quero fazê-los escutar a voz dos xapiri, que ali brincam sem parar, dançando sobre seus espelhos resplandecentes. Quem sabe assim eles queiram defendê-la conosco? Quero também que os filhos e as filhas deles entendam nossas palavras e fiquem amigos dos nossos, para que não cresçam na ignorância. Porque, 
se a floresta for completamente devastada, nunca mais vai nascer outra. Descendo desses habitantes das terras das nascentes dos rios, filhos e genros de Omama. São as palavras deles, e as dos xapiri, surgidas no tempo do sonho, que desejo oferecer aqui aos brancos. Nossos antepassados as possuíam desde o primeiro tempo. Depois, quando chegou a minha vez de me tornar xamã, a imagem de Omama as colocou em meu peito. Desde então, meu pensamento vai de uma para outra, em todas as direções; elas aumentam em mim sem fim. Assim é. Meu único professor foi Omama. São as palavras dele, vindas dos meus maiores, que me tornaram mais inteligente. Minhas palavras não têm outra origem. As dos brancos são bem diferentes. Eles são engenhosos, é verdade, mas carecem muito de sabedoria (KOPENAWA \& ALBERT, 2015, p. 64-65) ${ }^{4}$.

A publicização das próprias palavras e da própria ação, o que equivale à sua politização, possibilita que a sociedade em geral consiga ter acesso aos posicionamentos dos povos, dos escritores e dos intelectuais indígenas, tomando conhecimento de sua singularidade e de sua condição, bem como podendo compreender e avaliar suas reivindicações políticas. Como se pode perceber, repetimos mais uma vez, a correlação entre Movimento Indígena e literatura indígena aparece em cheio dessa condição de ativismo, de militância e de engajamento do eu-nós lírico-político expresso e dinamizado pela voz-práxis estético-literária indígena enquanto relato autobiográfico, testemunhal, autoral e mnemônico direto, constituído e enraizado em termos públicos, políticos e culturais. Ora, é nesse sentido que aparecem a quarta e a quinta características fundamentais da literatura indígena brasileira, a saber, a utilização do xamanismo como núcleo antropológico-normativo e epistemológico-político da autocompreensão, da autoexpressão e da autoafirmação do indígena por si mesmo e desde si mesmo e, a partir disso, sua postura de crítica social, de resistência cultural, de luta política e de práxis pedagógica - o xamanismo como, a um só tempo, permitindo a autoafirmação do indígena desde si mesmo e por si mesmo e levando-o àquela perspectiva de ativismo, de militância e de engajamento de que falamos acima, o que significa, portanto, que a literatura indígena tem como cerne e dinâmica a afirmação e a utilização da tradição com e como crítica do presente, desvelamento, denúncia e enfrentamento acerca da condição e da situação indígenas no país. Com efeito, no núcleo da literatura indígena brasileira, como estamos podendo perceber pelas passagens de Davi

\footnotetext{
${ }^{4}$ É importante mencionar-se, ainda que de passagem para este momento, que o texto A queda do céu: palavras de um xamã yanomami foi escrito em parceria entre Davi Kopenawa, liderança e xamã yanomami, e Bruce Albert, antropólogo francês que há décadas realiza pesquisas com os povos yanomami de Roraima, amigo e parceiro de longa data de Davi. Como o próprio Bruce Albert explica no post-scriptum ao referido texto, a autoria é definida como um texto escrito falado a dois, ou seja, Davi Kopenawa fornece o material narrado e Bruce Albert se encarrega de transcriá-lo, isto é, de traduzi-lo e adequá-lo à norma padrão e a conceitos mínimos próprios à cultura ocidental. Entretanto, o próprio Bruce Albert enfatiza o tempo todo que o conteúdo do texto é todo pertencente a Davi Kopenawa e, nesse caso, à tradição indígena que ele representa, situação que faz de Davi Kopenawa o efetivo autor do texto, e não apenas como informante do texto, junto, de todo modo, com Bruce Albert - e sem ignorar-se a ideia de um eu-nós lírico-político característico da literatura de autoria indígena, que definimos e utilizamos ao longo do texto (KOPENAWA \& ALBERT, p. 535-540).
} 
Kopenawa citadas anteriormente, está a busca pela reconstrução desse núcleo ontogenético, antropológico e normativo que constitui a singularidade-alteridade-diferença indígena, expresso em termos de xamanismo. Pudemos ver e ler que Davi Kopenawa se refere, o tempo todo, a Omama e aos Xapiri como o fundamento axiológico-antropológico que possibilita não apenas a compreensão e a expressão do indígena por si mesmo e desde si mesmo, mas também a compreensão e a fundamentação dessa totalidade metafísica, biológica e sociocultural que, de modo totalmente integrado, forma um organismo vivo, fundamentalmente normativo, do qual todos dependemos e que, por isso mesmo, deve ser preservado, protegido. No caso de Davi Kopenawa, portanto, o xamanismo permite-lhe a autoafirmação e a autoexpressão como indígena e lhe impulsiona a essa perspectiva ativista, militante e engajada, em termos de crítica social, fornecendo-lhe o arcabouço epistemológico, político e normativo para tal ${ }^{5}$. Desse modo, na literatura indígena, a afirmação e a utilização da tradição ancestral servem e levam, a um só tempo, à crítica do presente por parte do eu-nós lírico-político, que se serve dela para politizar nosso processo de modernização conservadora. Como se pode perceber, sem necessidade de assumir os pressupostos institucionalistas, cientificistas e tecnicistas próprios ao paradigma normativo da modernidade, os intelectuais indígenas podem, por meio do xamanismo, por meio da afirmação da sua tradição ancestral como crítica do presente, assumir uma perspectiva reflexiva, política-politizante e engajada que as vítimas - elas e somente elas - têm condições de realizar, de fundar, para além de qualquer racionalização imparcial, impessoal e neutra. E, com isso, a voz-práxis estéticoliterária indígena vai da autoafirmação e da autoexpressão identitárias, via xamanismo, à

\footnotetext{
${ }^{5}$ Queremos explicar que estamos utilizando o conceito de xamanismo em sentido lato, significando, com ele, a correlação entre as perspectivas social-cultural, natural e espiritual, que permite afirmar-se (a) a imbricação entre natureza e sociedade-cultura, inserindo-se, em verdade, a sociedade-cultura dentro desse horizonte amplo constituído pela natureza; bem como (b) o fundamento espiritual, vivo da própria natureza, a partir da ideia de que ela é perpassada por seres espirituais e tem um sentido autoconsciente e proativo relativamente a si mesma e a todos os seres - incluindo os seres humanos - nela contidos. Desse modo, a normatividade, que serve de base para a justificação e a validade de sujeitos, de normas e de práticas socialmente vinculantes, vem, no caso do xamanismo, seja da inserção da sociedade-cultura dentro desse horizonte amplo constituído pela natureza, seja pelo caráter vivo e autoconsciente, espiritualizado, da própria natureza, que passa a servir como modelo antropológico. Esse modelo de xamanismo talvez fique mais claro - pelo menos o utilizamos e o compreendemos desse modo - quando o associamos com o paradigma normativo da modernidade, que separa natureza e sociedade-cultura, atribuindo um sentido técnico à primeira (como res extensa) e um caráter normativo à segunda (res cogitans), não permitindo correlações e dependências recíprocas. No paradigma normativo da modernidade, a normatividade social advém da afirmação de que a razão humana possui um caráter criativo, dá sentido ao mundo circundante, sendo totalmente autossuficiente e capaz de fazer isso por si mesma e desde si mesma, sem necessidade do apelo à religião e à biologia. Outro ponto importante a ser ressaltado referentemente à utilização, por parte dos autores indígenas, de suas tradições étnicas, antropológicas e ancestrais, diz respeito ao fato de que o texto assim constituído transita da tradição para a crítica do presente, e desta para aquela, descrevendo um círculo hermenêutico-estético marcado permanentemente pela rememoração, pela repetição, pela redundância, em que o presente funde-se com o passado, o passado serve como paradigma para o presente, em que a pertença serve como esquema normativo para a crítica social e esta reatualiza e enfatiza àquela.
} 
critica do presente por meio do relato autobiográfico, testemunhal e mnemônico das experiências de marginalização, de exclusão e de violência vividas e sofridas em termos de colonização - em tudo isso, o xamanismo é o núcleo antropológico, normativo, epistemológico e político que enfatiza o poder da tradição indígena e seu sentido profundamente político e politizante, potencializando o ativismo indígena na esfera pública.

\begin{abstract}
Ao contrário, quando bebemos o pó de yãkoana como Omama nos ensinou a fazer, nossos pensamentos nunca ficam ocos. Podem crescer, caminhar e se multiplicar ao longe, em todas as direções. Para nós, é esse o verdadeiro modo de conseguir sabedoria.

Apesar de tudo isso, os brancos já nos ameaçaram muitas vezes para nos obrigar a abandonar os xapiri. Nessas ocasiões, só sabiam dizer: "Seus espíritos estão mentindo! São fracos e estão enganando vocês! São de Satanás!”. No começo, quando eu ainda era muito jovem, tinha medo da fala desses forasteiros e, por causa dela, cheguei a duvidar dos xapiri. Por algum tempo, me deixei enganar por essas más palavras e até tentei, com muito esforço, responder às palavras de Teosi. Mas isso acabou mesmo! Faz muito tempo que eu não deixo mais as mentiras dos brancos me confundirem e que não me pergunto mais: "Por que não tento virar um deles?". Tornei-me homem, meus filhos cresceram e tiveram seus próprios filhos. Agora, nunca mais quero ouvir más palavras sobre os xapiri! Omama os criou depois de ter desenhado nossa floresta e, desde então, eles continuaram cuidando de nós. Eles são muito valentes e muito bonitos. Seus cantos fazem nossos pensamentos aumentar em todas as direções e ficar firmes. E por isso vamos continuar fazendo dançar suas imagens e defendendo suas casas, enquanto estivermos vivos. Somos habitantes da floresta. É esse o nosso modo de ser e são estas as palavras que quero fazer os brancos entenderem (KOPENAWA \& ALBERT, 2015, p. 510-511).
\end{abstract}

\title{
Considerações finais
}

Ao longo do texto, procuramos desenvolver a ideia de que a literatura indígena brasileira emerge no cenário cultural brasileiro exatamente com o objetivo de dar voz e vez aos próprios indígenas, que, por meio dela, teriam condições de dinamizar uma voz-práxis direta em termos de esfera público-política, como sujeitos público-políticos, rompendo com mediações institucionalistas, tecnicistas e cientificistas que os relegariam a periferias e párias da constituição de nosso espaço público e de nossa vida político-cultural. Por meio da literatura, os escritores indígenas rompem com o silenciamento, a invisibilização e o privatismo a que tradicionalmente foram submetidos no contexto de nossa modernização conservadora, possibilitando, por conseguinte, a visibilização e a politização da condição e da causa indígenas e, como consequência, a pluralização dos sujeitos e das histórias acerca de nossa sociedade, a politização pungente de nossas instituições. Como fizemos ver ao longo do texto, a politização advém exatamente da pluralização dos sujeitos sociopolíticos, das histórias sobre a constituição de nossa sociedade e, em tudo isso, do embate entre essas diferentes - e em muitos casos antagônicas - histórias, entre os diferentes projetos de integração e de desenvolvimento, entre diferentes valores, práticas e símbolos definidores de nossa identidade coletiva. Por isso mesmo, como também argumentamos ao longo do texto, é 
muito interessante percebermos a correlação de Movimento Indígena e de literatura indígena enquanto o marco dinamizador e orientador do ativismo estético-literário, da constituição de uma voz-práxis estético-literária de caráter político e politizante, carnal e vinculado. A literatura de autoria indígena, com efeito, coloca essa perspectiva autoral concomitantemente como a base da autonomia pessoal, da autoafirmação grupal e, assim, da vinculação e do engajamento público-políticos em torno à condição e à causa indígenas, exatamente como o Movimento Indígena brasileiro o fez no que tange à luta por autonomia e por cidadania políticas: no primeiro caso, o da literatura de autoria indígena, rompe-se com - ou complementa-se - as representações institucionalistas, cientificistas e tecnicistas, os relatos extemporâneos sobre os povos indígenas por uma voz-práxis direta, por um relato construído pelos próprios indígenas; no segundo, substitui-se o paternalismo institucional e a tutela tecnocrática pelo enraizamento e pela militância diretos na esfera público-política, como sujeitos político-culturais afirmadores e utilizadores da cidadania enquanto condição fundamental da emancipação.

Ora, é interessante de se perceber que a atuação público-política, seja em termos do Movimento Indígena brasileiro, seja, para o nosso caso aqui, no que se refere à própria literatura de autoria indígena se dá sob a forma de um eu-nós lírico-político que vai da afirmação e da utilização de sua tradição, de sua pertença-singularidade étnico-antropológica à crítica do presente, a tradição como crítica do presente. Nesse sentido, a literatura indígena, enquanto ativismo, militância e engajamento na esfera pública, como sujeito político-cultural, é perpassada por dois pólos que, de todo modo, como estamos argumentando, sustentam-se e impulsionam-se mutuamente, a saber: (a) a reconstrução e a publicização da própria singularidade, da própria diferença, não apenas como uma marca identitária que leva à valorização de si, mas também como base, uma vez publicizada, para a luta social, para o reconhecimento cultural e para a transformação política, apontando exatamente para o fato de que as diferenças têm muito a dizer e a ensinar e a projetar no contexto de nossa sociedade brasileira de um modo mais abrangente; e, então, como consequência, (b) a constituição e a veiculação midiática, para toda a sociedade brasileira, de um relato autoral, testemunhal, autobiográfico e mnemônico da condição de marginalização, de exclusão e de violência vividas e sofridas pelos povos indígenas ao longo da evolução político-cultural da sociedade brasileira, um relato direto das vítimas de nossa colonização e, depois, de nossa modernização conservadora. Ambos os pontos são fundamentais e, como dissemos, dão esse profundo caráter político à literatura indígena: eles vão desde a desconstrução de caricaturas e de preconceitos e se constituem em catarse grupal, coletiva do lugar e da condição dos povos 
indígenas no Brasil de ontem e de hoje, mas também - e por isso mesmo - eles performatizam uma perspectiva catártica relativamente à própria versão coletiva de nossa história nacional institucionalizada e idealizada, de seus caminhos e de seus sujeitos modelares, de suas práticas e de seus valores hegemônicos, pluralizando sujeitos, histórias, valores e práticas e, portanto, trazendo a contradição para dentro da política e da educação via voz-práxis estéticoliterária. Ora, é exatamente pela visibilização do próprio lugar de fala, que traz à tona sujeitos, histórias, valores e práticas marginalizados, silenciados, calados, deslegitimados, que aprendemos na pluralidade e por meio dela, que nos tornamos mais democráticos e mais políticos, posto que não se pode estar mergulhado nas diferenças sem politizar-se, sem tomar consciência delas, de si e do lugar que todos ocupamos; não se pode ver as diferenças em passividade - elas nos fazem amá-las ou odiá-las, escutá-las ou recusar-lhes reconhecimento, mas nunca nos deixam intocados; e essas mesmas diferenças, como fizemos ver ao longo do texto, não podem aparecer, agir e falar publicamente sem politizar-se e politizar o meio de que fazem parte e os sujeitos com os quais se relacionam. Produzidas por relações de poder, por violência simbólico-material, silenciadas, marginalizadas e invisibilizadas, seu enraizamento na esfera pública, como sujeitos político-culturais, leva diretamente à politização radical. É sua sina, da qual elas não podem fugir: reconhecimento abrangente, crítica social aguda e ativismo político são sua necessidade permanente, seu destino, caso não quiserem perecer. E isso também significa que, ao resistirem como diferenças, como minorias, elas também contribuem de modo efetivo para a democratização da sociedade em que estão inseridas, que as produziu como negatividade. Com efeito, a democracia se funda, se dinamiza, se aperfeiçoa e se matura pelas diferenças - sem elas, entramos no reino da massificação e da unidimensionalização e, portanto, deixamos de aprender.

\section{Referências}

ALMEIDA, Maria Inês de; QUEIROZ, Sônia. Na captura da voz: as edições da narrativa oral no Brasil. Belo Horizonte: Autêntica; FALE UFMG, 2004.

JEKUPÉ, Olívio. Literatura escrita pelos povos indígenas. São Paulo: Scortecci, 2009.

KOPENAWA, Davi; ALBERT, Bruce. A queda do céu: palavras de um xamã yanomami. Tradução de Beatriz Perrone-Moisés. São Paulo: Companhia das Letras, 2015.

KRENAK, Ailton. Encontros. Organização de Sergio Cohn. Rio de Janeiro: Azougue Editorial, 2015. 
KRENAK, Ailton. Ailton Krenak. Organização de Sergio Cohn e de Idjahure Kadiwel. Rio de Janeiro: Azougue Editorial, 2017.

MUNDURUKU, Daniel. Memórias de índio: uma quase autobiografia. Porto Alegre: EDELBRA, 2016.

MUNDURUKU, Daniel. O caráter educativo do movimento indígena brasileiro (19701990). São Paulo: Paulinas, 2012.

MUNDURUKU, Daniel. Mundurukando 2: sobre vivências, piolhos e afetos - roda de conversa com educadores. Lorena: U'KA Editorial, 2017.

POTIGUARA, Eliane. Metade cara, metade máscara. São Paulo: Global, 2004.

ROMERO, Francisco Javier. La literatura indígena mexicana en búsqueda de uma identidad nacional. In: XXXVIII Congreso Internacional Instituto Internacional de Literatura Iberoamericana Independencias: Memoria y Futuro, 9 a 12 de junio de 2010, Georgetown University, com colaboración de George Washington University y Universityof Maryland, College Park. Disponível em: http://www.iiligeorgetown2010.com/2/pdf/Romero.pdf. Acesso em: 10 fev. 2018.

THIÉL, Janice. Pele silenciosa, pele sonora: a literatura indígena em destaque. Belo Horizonte: Autêntica Editora, 2012.

TUKANO, Álvaro. Álvaro Tukano. Organização de Sergio Cohn e de Idjahure Kadiwel. Rio de Janeiro: Azougue Editorial, 2017.

VALENTE, Rubens. Os fuzis e as flechas: história de sangue e resistência indígena na ditadura. São Paulo: Companhia das Letras, 2017.

WERÁ, Kaká. Kaká Werá. Organização de Sergio Cohn e de Idjahure Kadiwel. Rio de Janeiro: Azougue Editorial, 2017.

WERÁ, Kaká. Ore Awé Roiru'a Ma: todas as vezes que dissemos adeus. São Paulo: TRIOM, 2002.

WERÁ, Kaká. A terra dos mil povos: história indígena brasileira contada por um índio. São Paulo: Peirópolis, 1998.

ZANCAN, Márcia Rejane Kristiuk. “A literatura canônica e a voz do indígena”. Litterata, vol. 6/2, jul-dez, ISSN 2237-0781, p. 59-70, Ilhéus, 2016.

Recebido em: 03/01/2019

Aceito para publicação em: 18/03/2019 